\title{
The parable of the shrewd manager (Lk 16:1-8): A biography of Jesus and a lesson on mercy
}

\begin{tabular}{|c|c|}
\hline \multicolumn{2}{|c|}{$\begin{array}{l}\text { Author: } \\
\text { Dieter H. Reinstorf }{ }^{1}\end{array}$} \\
\hline \multicolumn{2}{|c|}{$\begin{array}{l}\text { Affiliation: } \\
{ }^{1} \text { Department of New } \\
\text { Testament Studies, } \\
\text { University of Pretoria, } \\
\text { South Africa }\end{array}$} \\
\hline \multicolumn{2}{|c|}{$\begin{array}{l}\text { Note: } \\
\text { Dr Dieter H. Reinstorf } \\
\text { (MDiv, DD) is Pastor of } \\
\text { the Evangelical Lutheran } \\
\text { Immanuel Congregation, } \\
\text { Pietermaritzburg, and } \\
\text { also Bishop of the Free } \\
\text { Evangelical Lutheran Synod } \\
\text { in South Africa. Dr Reinstorf } \\
\text { is a research associate of } \\
\text { the Department of New } \\
\text { Testament Studies in the } \\
\text { Faculty of Theology at } \\
\text { the University of Pretoria, } \\
\text { directed by Prof. Dr Andries } \\
\text { G. van Aarde. }\end{array}$} \\
\hline \multicolumn{2}{|c|}{$\begin{array}{l}\text { Correspondence to: } \\
\text { Dieter Reinstorf }\end{array}$} \\
\hline $\begin{array}{l}\text { Email: } \\
\text { dieter.reinsto }\end{array}$ & rf@gmail.com \\
\hline \multicolumn{2}{|c|}{$\begin{array}{l}\text { Postal address: } \\
\text { PO Box 21559, Mayors Walk } \\
\text { 3208, South Africa }\end{array}$} \\
\hline \multicolumn{2}{|c|}{$\begin{array}{l}\text { Dates: } \\
\text { Received: } 15 \text { Feb. } 2013 \\
\text { Accepted: } 30 \text { Mar. } 2013 \\
\text { Published: } 27 \text { May } 2013\end{array}$} \\
\hline \multicolumn{2}{|c|}{$\begin{array}{l}\text { How to cite this article: } \\
\text { Reinstorf, D.H., 2013, 'The } \\
\text { parable of the shrewd } \\
\text { manager (Lk 16:1-8): A } \\
\text { biography of Jesus and } \\
\text { a lesson on mercy', HTS } \\
\text { Teologiese Studies/ } \\
\text { Theological Studies 69(1), } \\
\text { Art. \#1943, } 7 \text { pages. http:// } \\
\text { dx.doi.org/10.4102/hts. } \\
\text { v69i1.1943 }\end{array}$} \\
\hline \multicolumn{2}{|c|}{$\begin{array}{l}\text { Copyright: } \\
\text { C 2013. The Authors. } \\
\text { Licensee: AOSIS } \\
\text { OpenJournals. This work } \\
\text { is licensed under the } \\
\text { Creative Commons } \\
\text { Attribution License. }\end{array}$} \\
\hline Read online: & \\
\hline 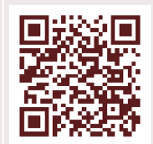 & $\begin{array}{l}\text { Scan this QR } \\
\text { code with your } \\
\text { smart phone or } \\
\text { mobile device } \\
\text { to read online. }\end{array}$ \\
\hline
\end{tabular}

Many scholars have regarded the parable of the shrewd manager (Lk 16:1-8) as the most puzzling of all parables as Jesus seems to use the unrighteous actions of a dishonest (worldly) manager as a model for emulation by others. The unease associated with this understanding was managed in part by focusing almost exclusively on the 'shrewdness' of the dishonest manager. In this interpretation, it is not his unjust behaviour that is to be imitated but his wise and intelligent actions. This interpretation has led to a divergence of applications regarding the 'property' that was entrusted to him. The author, however, argues that, in the context of the historical Jesus, the entrusted property in the parable references first and foremost the Torah entrusted to God's people and that the manager mirrors the life of Jesus, who was 'accused' by the religious leaders of being unjust. Despite being threatened, he continued unabatedly to scatter God's mercy, epitomised by the reduction of debt and symbolising the dawning of God's Kingdom. The manager is therefore not a negative figure but a positive (diaphorical) example of what it means to be a faithful manager of God in the light of adversary and opposition.

\section{Introduction}

Has contemporary interpretations of Scripture led to a crisis concerning God's Word? This was the implicit question raised at the 2012 International Lutheran Council (ILC) World Conference held in Niagara Falls, Canada, under the theme: What does it mean? How do the Scriptures speak to the crisis facing confessional Lutherans today? The primary questions being addressed by confessional Lutherans are those of same-sex marriages and the ordination of women into the office of the church. There is little doubt that these questions have caused a rift amongst Christian worldwide. For the majority of churches and scholars in South Africa, these particular questions may have been largely settled some time ago, but globally, the debate is still raging. One example - arguing against the ordination of women - is the recent publication (handed out at the conference) entitled Women Pastors? The ordination of women in biblical Lutheran perspective (Harrison \& Pless 2012).

My particular task at the conference was confined to doing the morning Bible Studies based on those parables of Jesus that relate to the Word and its power for proclaiming and living. This provided me with the opportunity to raise a concern of a different nature, namely that scholars and church leaders are often so consumed by their internal and inter-church hermeneutical 'battles' that the mercy of God, so central to Scripture and epitomised by the life of Jesus, is sacrificed on the altar of 'truth'. Being a confessional Lutheran myself, the search for truth and remaining faithful both to God's Word and to the Lutheran Confessions is central. However, when the church of Christ is no longer formed and characterised by mercy - even as it debates its theological and hermeneutical differences - there is indeed a crisis of a different kind that needs to be addressed. Invariably this crisis is addressed by the parables told by Jesus.

My own parable research, in particular my doctoral dissertation under the supervision of Andries van Aarde (Reinstorf 2002; see also Reinstorf \& Van Aarde 1998:603-622), has led to a number of theses that guide and inform me as I interpret Jesus' parables. The first three already formed part of my doctoral studies which focused in particular on those parables peculiar to Luke, and they have been expounded by various scholars worldwide. The last one has found shape more recently.

Needless to say, theses are models of interpretation. A model is not a complete picture but a simulation of reality from a certain point of view. It functions as a lens that focuses on a specific area or a map that enlarges one area of an otherwise complex system. Furthermore, the named theses do not suggest that they need to be equally prevalent in each and every parable of Jesus, be it the context of the historical Jesus or the narrative world of the Synoptic writers. 
The first thesis is that Jesus' parables are to be read as metaphorical stories. The whole story - and not just one particular point - is relevant. As a teacher who challenges conventional views, Jesus' parables are mostly subversive stories and feature predominantly as diaphors that challenge the listener or reader to see reality differently. As I study the parables of Jesus, I therefore always look for the juxtaposition of dissimilarities, the diaphor, resulting in the unexpected twist in the story, something that will shock the listener. If such a twist is not immediately apparent, it could be that I failed to read the parable within its 1st-century social, economic or political context.

Secondly, the parables of Jesus are creative language events. Jesus does not simply convey knowledge with his stories by means of fictive illustrations. The everyday stories draw the listener into the story. However, once the listeners are in the story, it either provides them with a promise or a challenge that does not illustrate a new reality but creates that reality. Jesus' parables are by nature speech acts.

Thirdly, the parables of Jesus are inherently about the Kingdom of God. Although Jesus addresses various social, economic and political issues in his parables and uses these to impact on his listeners, the parables serve the purpose of conveying to his listeners a vision of the Kingdom of God: the new realm that is dawning upon them as he speaks and as they are listening. The parables form part of Jesus' core message that the Kingdom of God is near (Mk 1:15; Lk 9:2; 10:9).

Fourthly, Jesus' parables mirror the life of Jesus. Jesus does not simply announce the coming of God's Kingdom, the promised malkût Jahwe [kingdom of Jahwe], but embodies the dawning Kingdom of God, even as He speaks and tells his stories. 'When the blind receive sight, the lame walk, those who have leprosy are cured, the deaf hear, the dead are raised and the good news is preached to the poor' (Lk 7:22), the Kingdom of God is amongst them in the person of Jesus himself (cf. Lk 17:20-21). Being the embodiment of God's dawning Kingdom, the parables mirror (in certain aspects at least) the life of Jesus. As such Jesus himself is God's parable, his speech act.

This fourth thesis is based primarily on the work of Georg Baudler, Jesus im Spiegel seiner Gleichnisse, which was already published in 1986 but overlooked by me in my initial studies of Jesus' parables. His work does not suggest that Jesus is always referenced directly or even indirectly in every single parable but that the parables told by Jesus express metaphorically his own experience of the dawning kingdom of God in and through him. These parables are also a reflection not only of the message he proclaimed but also of the life that he lived. Baudler (1986:30-31) is well aware of the fact that the Synoptic writers assimilated and (re)interpreted these parables within their own context, but he contests that such (re)interpretations, often with strikingly different applications, are nevertheless informed by the core message of God's kingdom and the life of the historical Jesus.
These four theses will also guide my interpretation of the parable of the shrewd manager. However, the fourth thesis is the primary lens used to unravel the puzzle posed by this parable that has led to a divergence of interpretations that continue to challenge contemporary scholars. ${ }^{1}$

\section{The puzzle}

The parable of the shrewd manager is widely regarded as the most puzzling of all parables (Forbes 2000:152; Hultgren 2000:146-147). The puzzling or even disturbing factor is that Jesus seems to use unrighteous actions as a model for emulation by others.

That Jesus uses questionable characters in his parables is, of course, in itself not unusual. In the parable of the Good Samaritan (Lk 10:25-37), the Samaritan is used diaphorically as the one who does what the Law demands, '[l]ove your neighbour as yourself' (10:27b), least expected by an Israelite audience. Likewise the tax collector in the parable of the Pharisee and the Tax Collector is also used diaphorically as the one whose prayer is answered and goes home justified before God (Lk 18:9-14). In both cases, deplorable characters in 1stcentury Palestine are used as positive examples of life within the kingdom of God challenging conventional worldviews. But then again, although these characters are viewed by the Israelite populace (in particular by the religious elite) as deplorable, their actions within the parables of Jesus are not. Unlikely and unexpected as it may be, the hated Samaritan is a neighbour to the man who fell amongst the robbers, and he does what the Law commands. And the equally despised tax collector, who cheats God's own people, humbles himself before God.

The actions of the manager in Luke 16, however, can hardly be justified. He is - as it seems - a trickster who has but one goal in life: Self-survival. In the case of Luke 16, not only the character is negative (especially as viewed by the largely exploited peasantry), but his actions, commended by the master, are negative as well.

This has led to an array of questions concerning both the original ending of the parable and the identity of the master (ho kyrios). The argument turns on the referent of the master who 'commends the dishonest/unrighteous' manager (16:8a). For Joachim Jeremias ([1963] 1984:182), for example, the parable ends with verse 7 as it is unlikely that Jesus would have praised this manager. Others, like Joseph Fitzmyer (1964:23-42), argue for the master to be the rich man (plousios) in the story as the parable otherwise has no proper ending. Others tried to defuse the tension by

1.For this interpretation, I shall focus on verses $1-8$, verse 8 being widely regarded as the ending of Jesus' parable, followed by Luke's explication in verses 9-13. For a summary of scholarly debate on the proper ending of the parable, see Scott (1990:256-260) and Herzog (1994:233-237). Contemporary debate centres largely (1990:256-260) and Herzog (1994.233-237). Contemporary debate centres largely on the question whether the parable ends with verse $8 \mathrm{a}$ or $8 \mathrm{~b}$. The attachment formula at the beginning of verse 9, ' $a$ ]nd I tell you', suggests that it is a late addition and introduces one of Luke's favourite themes, that of wealth and support for the poor. Verse $8 \mathrm{~b}$ remains in dispute. It can be seen as an early attempt to explain the commendation of the manager in verse $8 \mathrm{a}$ or represents the lesson of the manager's story in an eschatological framework. The choice of ending, however, be it verse $8 \mathrm{a}$ or $8 \mathrm{~b}$, hardly affects the thesis put forward in my own interpretation of the parable. 
focusing on the word unrighteous (tes adikias) in verse 8 (with reference to Luke 18:6, the 'unjust' judge) and noted that this phrase can denote an ordinary man 'of this world' and not necessarily a person of special wickedness (Ellis 1974:199, cited by Wright 2000:227). It is also noted that, in reducing the debt, the manager was not really dishonest as he was only reducing hidden interest that was added to the contract (cf. Herzog II 1994:246).

The common way of interpreting this parable since Adolf Jülicher has been to seek for the single point of comparison. Once the tertium compariationis between Bild and Sache had been discovered, the rest of the details in the parable purely served as décor. The single point of comparison is the 'shrewdness' of the manager. Whether his actions were good or evil, righteous or unrighteous, is largely irrelevant. The comparison is solely between 'the children of the world who are shrewder in dealing with their own kind than are the children of the light' (16:8b). Although the parable itself does not disclose in what areas of life the followers of Jesus (or the children of light) need to show more shrewdness, the proceeding passage (16:10-15) seems to indicate that it relates to money matters and that the children of the light should learn to use worldly wealth $(18: 11)$ prudently for kingdom purposes.

\section{Backdrop, meaning and recent applications of the parable}

Historical and in particular social-scientific research has provided interpreters with a wealth of information, which serves primarily to highlight the 'shrewdness' of the manager in a hopeless situation with all odds stacked against him. The repertoire on which the story draws is that of a patron-client model (see inter alia Malina 1988:2-32; Malina \& Rohrbauch 1992:74-76; Moxnes 1991:241-268). The master is clearly a very rich man, possibly a landowner. Whether he lives on an estate or is an absent landlord is largely irrelevant. Landowners employed managers to carry out the business of their estate. They could make sales and loans, and they could collect and pay off debts for their masters. They were men of considerable authority, not slaves, but retainers, who, on mismanaging a master's estate, could only be punished by dismissal and shame (cf. Herzog 1994:233-258; Scott 1990:255-266). Although powerful, the managers occupied a vulnerable position. On the one hand, they were to realise a profit large enough to support their master's luxurious lifestyle. The masters, in turn, would not be concerned about the managers' profit as long as they produced the expected yield. If, however, this yield was not forthcoming, a case of mismanagement could be made. On the other hand, however, they faced the continual complaints of the tenants regarding excessive greed and exploitation. Of course, they could not complain to the master, as the master would take such a complaint as a testimony to the managers' thoroughness. If, however, the managers became too rich, it would further entrench the general perception of the peasants that all rich people are thieves (see Malina 1993:104) who - within a limited good society - steal from their slice of the pie. As a result, there was a high level of distrust on all sides, more often than not levelled at the managers.

In the parable, the manager is 'accused' (with hostile intent - dieblethe) of mismanaging his master's estate. One can surmise that the hearers would have expected the manager to launch a long and loud protestation of his innocence on these false charges. That he does not do so could indicate the irremovable nature of the master's judgement and the futility of engaging the accusers. He considers his options. The refusal to dig or to beg is not just a matter of preserving one's own status (dropping out of the class of retainers into the class of expendables) but is a hardly plausible option of survival. The manager would have to compete for jobs with peasants who have worked all their lives (Herzog 1994:242). As he loses the little strength he has, he would become a beggar until - like Lazarus and thousands of others - he would die of malnutrition and other diseases.

What does the manager do to ensure a future for himself? He calls in each one of his master's debtors. His actions correlate with the nature of debt made. Although the Torah clearly forbids usury, that is, lending money at unreasonably high rates of interest (Ex 22:25-27; Lv 25:36-38; Dt 15:7-11:2; 23:19-20), the wealthy always found ways to charge interest under other guises. The most common tactic, according to William Herzog (1994:242), was to include the total amount of debt incurred in a single figure that included principal and interest. In other words, interest rates were hidden and subsumed under the single amount charged.

There is considerable debate on how interest was calculated and on the unequal debt reductions made by the manager. Some scholars have suggested that goods were ranked in order of risk and that the higher the risk the higher the interest (cf. Herzog 1994:154-155; Wright 2000:226). The reductions in debt (16:4-8) could then possibly represent the difference between the ostensible value of the contract and the hidden interest rate, $50 \%$ on oil and $20 \%$ on wheat.

Although the exact nature of these legal proceedings remain unclear (see Kloppenberg 1989:479-486, cited by Herzog 1994:155), the peasants who accepted the reduced debt would have been indebted to the manager and obliged to reciprocate in kind (cf. Malina \& Rohrbauch 1992:41-43, 76-77). However, on the public stage, the tenants would praise and honour their glorious patron and benefactor. The master could either have accepted the praise and retained his manager, or he could have cancelled the renegotiated contracts and made a martyr of the manager. It is clearly wiser to retain the manager and accept the praise and the accompanying honour of the peasants. Present losses would be made up at a later stage. The wealthy never loose. The manager was indeed very shrewd. This is and remains, also amongst most contemporary scholars, the single point of comparison.

In spite of widespread consensus that the meaning of the parable is guided by the shrewdness of the manager, the 
meaning(s) of the parable and its application(s) vary. For William Herzog (1994:252-258), the parable shows how the weapons of the weak can produce results in a world dominated by the strong. The master who held all the cards lost his hand. Out of the battle, based on the shrewdness of the manager, came a temporary respite for the debtors, which could possibly be seen as a glimpse of a time when debts would be lowered and rejoicing could again be heard.

Brandon Scott (1990:245-246) argues that the hearers of the parable would have supported the unrighteous actions of the manager as a reaction to the exploitation of the peasantry by the elite. He also sees the diaphor in the master's praise of the manager. For him, however, praise runs contrary to the expectation of punishment. Instead of punishing his manager, he surprisingly praises him. The audience, having sanctioned the unrighteous behaviour of the manager, needs to reconsider its prejudices. Are masters (always) cruel? Are victims right in striking back? The Kingdom of God is for the vulnerable, both masters and managers, who do not get even, which in part correlates with the preceding parable of a Man who had Two Sons (Lk 15:11-31). The father refuses to choose between his sons but patiently waits for both of them to come home.

For Arland Hultgren (2000:153-154), the manager is so clever, so wise, that the landowner cannot but be amazed. It is an epiphor for the children of this age, who have learned to use the system of reward and punishment to make plans for themselves as far as their working years and retirement are concerned. In telling this parable, Jesus challenges the children of the light to measure up in wisdom, realising that they stand before God with the final judgement to come.

Stephen Wright (2000:228) has a slightly different viewpoint. He argues that the disciples of Jesus are exhorted to look to the 'sons of the world' as examples, rather than to the 'sons of the light', the latter referring to 'self-styled' sons of the light - like the sectarians at Qumran (who applied this phrase to themselves) or the Pharisees, who seem to have taken over for themselves the prophetic designation 'a light to the nations' (cf. Is 42:6).

As most other scholars, Graig L. Blomberg (2004:89-93) also stresses that the parable is not about dishonesty but shrewdness. Not the unjust behaviour is to be imitated but the wise, clever, resourceful, intelligent actions of the manager - whilst remaining innocent of all evil. For him, the parable addresses a topic frequently addressed by Jesus and one of Luke's most favourite themes - the right use of money further exposed by Luke in the verse 9-14. His application, however, covers various aspects of church life:

- Finances: In learning to use money shrewdly, we should save and give generously to charitable causes instead of running up debts. We should not 'buy' friends but use our material resources for kingdom priorities - to disciple and win others (with an emphasis on 'graduated' tithing - the more I have, the more I give).
- Church programmes: In considering what will attract other unbelievers, we could learn from parachurch organisations that target the youth. Too little thought also goes into Sunday school where many Christian typically give far less thought to teaching Sunday-school lessons than lessons at a 'real' (private or public) school.

- Political and social activities: Too many churches divorce themselves from the political arena or fail to become involved in social activities that uplift the life of the poor, thereby creating greater receptiveness for the Gospel message.

- Holiness and morality: Greater shrewdness and less naiveté need to be displayed in, for example, working on our relationship with God and finding a balance with other recreational activities.

Although 'shrewdness' is central to the meaning of the parable, there seems to be little consensus on the meaning of the parable and its applications (be it in the historical-Jesus, Lukan or contemporary contexts). Various puzzle pieces have not found its place in the larger picture of Jesus' story. Does Jesus indeed use the negative figure of a (worldly) manager being accused of mismanagement as an example of shrewdness for his disciples, in particular with regard to money matters? The difficulties relating to this train of thought are compounded by the statement in the proceeding passage that whoever is dishonest with very little will also be dishonest with much $(18: 12 b)$ and that anybody not trustworthy with 'worldly wealth' cannot be trusted with true (spiritual) riches (18:13).

Fact is, when the evil actions of a negative figure are reinterpreted to serve as a positive example, it leaves both listeners and interpreters of this parable with an uneasy feeling. This in itself does not disqualify the above interpretations, but it does warrant a new look at the parable based in particular on the fourth thesis presented above, namely that the parables of Jesus mirror the life of Jesus.

\section{The 'shrewd' manager as a biography of Jesus}

Jesus in the role of the accused manager - for this metaphorical interpretation, which looks at the parable as a whole and not only at the aspect of 'shrewdness', I am indebted to Georg Baudler (1986:217-230) and Gisela Kittle (2002/2003:506-512). That Jesus is to be seen in the role of the accused manager is of course a shocking diaphor that should make the listeners sit up and listen. It is a reading that is supported by some of the finer details of the parable.

Firstly, clarity needs to be gained on what the possessions (hupargonta), which the plousios had entrusted to his manager (oikonomos) could reference. Baudler (1986:187, 221-222) advocates that, at the time of Jesus, 'entrusted possessions' was a terminus technicus for the Torah, entrusted by God to his people. Metaphorically it therefore references the Word of God, in particular the messianic promises of God. For Baudler (1986:224), this clarity of reference distinguishes 
the metaphor from the allegory. The allegory's reference is hidden and needs to be revealed. The metaphor's associations are obvious to all, and every listener of Jesus' parable on hearing the term 'entrusted possession' would immediately draw the association with the Torah at whose heart lies the mercy of God who graciously chose Israel from all nations and gave it his Torah to be a light to all nations.

In this particular parable, the entrusted hupargonta are not clearly defined. The same word, however, also features in Jesus' parable of the talents (Mt 25:14-30). There a man leaving his home delivers or entrusts his hupargonta [possessions] to his servants. It is then defined as talanta [sum of money] (Mt 25:15; in Luke 19:13, minas [sum of money]). Again there is extensive scholarly debate on what the hupargonta (be it the talanta in Matthew's Gospel or the minas as the implied hupargonta in Luke's Gospel) could reference in the context of the historical Jesus (see Van Eck 2011:254-264). Although van Eck comes to a different conclusion, various scholars support the notion of 'possessions' referencing God's revelation entrusted to the religious leaders of Israel (see Van Eck 2011:257). As such, the parable conveys the shocking diaphor that, in contrast to the entrusted possessions being buried for their preservation and protection (action of the last servant), they should be used for kingdom purposes (action of the first two servants).

The metaphorical association of an entrusted object being the Torah is reinforced by a rabbinic parable, sometimes called A Man Entrusted Property. The parable is told by Rabbi Eleasar, who attempts to console his colleague, Rabbi Johanan ben Zakkai, upon the early death of his son:

I shall tell thee a parable: to what may this be likened? To a man with whom the king deposited some object. Every single day the man would weep and cry out, saying: 'Woe unto me! When shall I be quit of this trust in peace?' Thou too, master, thou hast a son: he studied Torah, the Prophets, the Holy Writings, he studied Mishnah, Halakha, Agada and he departed from the world without sin. And thou shouldst be comforted when thou has returned thy trust unimpaired. (Scott 1990:230, [emphasis added])

Although Jesus' parable of the talanta or minas challenges the conventional view expressed above of keeping the Torah unimpaired through safekeeping, the metaphorical association is obvious: The entrusted object references the Torah, the Prophets and the Holy Writings, that is, God's revelation to his people.

Secondly, it needs to be observed that the manager of the rich man is 'accused' of wasting his possessions. The parable does not start with the line, 'There was a rich man that had a dishonest manager' but only that he was 'accused' as such. That the accusations were made with evil intend is highlighted, as noted before, by the word dieblethe, which is a morpheme of diabolos (devil). The manager is being 'bedeviled'. Especially striking is that the manager is not accused of fraud or embezzlement for personal gain. The charge levelled at him is that he has 'wasted' or 'scattered' (diaskorpisein) his master's possessions.
The accusations that Jesus was scattering God's grace are common within the Synoptic Gospels. It is the very accusation levelled at Jesus by the Pharisees and the teachers of the Law in Luke 15:1 - with hostile intend. Wastefully or lavishly scattering God's grace, Jesus welcomed sinners and ate with them. Elsewhere he healed the sick, exorcised the demons from the possessed and spoke forgiveness to those barred from the temple based on their (perceived) state of uncleanliness.

Jesus' actions, however, unleashed the wrath of his opponents, the religious leaders of Israel. Jesus is accused of being lawless, being a 'Samaritan' and a 'demon-possessed' (Jn 8:48), whose power to drive out demons is received from the prince of demons himself, Beelsebub (Lk 11:15). That these accusations, accompanied with negative labelling, were without merit is the golden thread that runs through the Gospel narratives. The manager in the parable, if he indeed references Jesus, is therefore not dishonest. The word 'dishonest' does not reflect an objective truth but an evil and unwarranted accusation. Accordingly also the word 'dishonest' in the master's appraisal of his manager, 'The master commended the dishonest manager' (16:8) needs to be put in inverted commas (see Baudler 1986:222). Not a single act in the story confirms dishonest behaviour. This is further supported by the word 'hos' in verse 1: 'There was a rich man whose manager was accused as [or, as if] wasting his possessions.'

In Luke's Gospel, the parable forms part of Luke's travel narrative, a description of Jesus' journey towards Jerusalem where He expected his ministry and life to be cut short (cf. Lk 12:50; 13:33-34; see also Mk 10:38). What, however, is his reaction to the accusations and the threat of losing his 'job'? Like the manager in the parable, he is not perturbed by the accusations but scatters his master's possessions even more consistently than before, reducing one debt after the other. The parable of the talanta and minas points in the same direction. Jesus' action (and those of his followers) is not to be identified with that of the third servant who, fearing the impairment of the 'entrusted possessions', digs a hole to preserve them. Instead set free from all fear, he works with them to gain more, unflustered by accusations of lawlessness.

Scattering God's possessions unabatedly in difficult times under a cloud of accusations does not only characterise the life of Jesus as it does most prophets who lived before him (Mt 5:12), but it is divine 'wisdom' (fronimos). Translating fronimos with 'shrewdness' is prejudiced, based on a negative perception of the manager in the parable. Louw and Nida (1988:834) translate fronimos with 'wise, wisely, with understanding and insight' (see also Mt 7:24). There is no undertone of falsehood or evilness. This 'wisdom' for which the manager is commended by his master is therefore hardly based on the negative example of a 'dishonest' manager, but rather on the life of Jesus who is accused of being dishonest by his opponents and labelled negatively, not least of all 
by means of the patron-client repertoire associated with an exploitive society. Scattering God's prized possession and reducing debt is wisdom, not of this age, but of the Spirit of God (cf. 1 Cor 2:6-16).

\section{Wisdom, mercy and truth}

In Luke's Gospel, the parable is directed at the 'disciples of Jesus' (16:1). It raises the question: Where do they (and where do we) feature in this parable? In a rather personal application and as a response to the ecclesiastical 'battles' often fought on the basis of discovering and preserving the truth of the Gospel, I would like to propose two levels of reading, the first being essential before the second level can be attempted. Failure to do so will lead to an ill-fated identification with the manager that will obscure the very intend of the parable.

On a first-level reading, we are not the manager who generously scatters God's possession (his Word of grace, forgiveness and mercy) and continues on his journey to the very end in spite of adversary. We are the debtors in the parable whose debt is graciously reduced and finally totally cancelled (cf. Col 2:14). It is a huge debt: 800 gallons of olive oil, 1000 bushels of wheat, hardly repayable. An experience of and the continued awareness of God's extravagant grace, however, opens the door to a restored relationship and a new home for a united family of God.

It is only when the realisation of indebtedness to God and his unfailing mercy dawns on the reader that the reader then can and should - on a second-level reading - also identify with the manager, the protagonist in Jesus' story. In his first letter to the Corinthians, Paul writes that 'men out to regard us as servants/managers [oikonomous] of Christ and as those entrusted with the secret things of God' (1 Cor 4:1). Being a wise or a faithful manager means that, despite opposition and false accusations, we - like Jesus himself - should scatter God's possessions freely and generously. For us, this is first and foremost the Gospel message of a merciful God, but it also applies to all other goods that we graciously receive from God, including money - as highlighted by the Lukan context. Divine wisdom is a matter of giving, not hoarding for personal gain.

This application widely coheres with a recently published article by Andries van Aarde (2012:277-287) in which he explores the three Sondergut parables in Luke 15 and 16. At the time of doing my own analysis of Luke 16, this publication was not known to me. Although his approach, as well as the context from which he writes, differs from my own, the results are strikingly similar. His exposition of the parable is done against the backdrop of power, not least of all the abuse of power so prevalent in patron-client relationships. Jesus himself experiences the abuse of power whereby he is placed under pressure by the religious leaders of Israel to avoid contact with 'tax collectors and sinners' - all in an effort to safeguard the pureness of the Torah and the cleanliness or holiness of God's people. This particular manager, however, resists becoming part of an exploitive system where those in power and having honour serve the mammon of money and instead of 'showing mercy to the weak' (the essence of God's Kingdom) exploit them for personal gain. In his application, Van Aarde suggests that the manager is the liberated (not liberal) 'dominee' [pastor], who is indeed the 'faithful servant' who scatters freely and generously the grace and mercy of God to the undeserving. Against the interest of those in power, he is loyal to the weak, which in turn speaks for his credibility as a faithful oikonomos who fulfils the heart of the Torah. As a result of his loyalty, he (might) loose his 'job', but he gains friends that are not bought but are the fruit of the merciful actions that characterise the dawning of God's eternal Kingdom.

'Cheap grace' (Dietrich Bonhoeffer) cannot be equated with the Kingdom of God or the truthfulness of God's Word. However, where there is pureness of God's Word, there is always grace and mercy. Likewise 'light' cannot simply be equated with our human effort to safeguard the pureness of Gods' Word. Being 'children of light' (Lk 16:8) is not a selfmade declaration, it is something we become when Christ is embedded in us and we experience God's unmerited mercy. Indeed followers of Christ are children of the light because 'they have been rescued out of the domain of darkness and brought into the kingdom of the Son he [God] loves, in whom we have redemption, the forgiveness of sins' (Col 1:13-14).

According to 1 Peter 2:21, we should follow in the (foot) steps of Jesus. In the words of this parable, we are to imitate the wise manager and scatter the possessions of God, the richness of his grace, extravagantly and lavishly and act wisely in determining what stands the test of time and be merciful as He his merciful (cf. Lk 6:36), all the more so in times of adversary and conflict.

\section{Conclusion}

Interpreting this parable as a biography of Jesus, his life being mirrored in that of the unfairly accused manager, is not new - just new to me. Whether more pieces of the puzzle have found their place in the larger picture remains an open question that can be debated. However, there is little doubt that Jesus faced many false accusations but continued to scatter the Word of God lavishly and consistently - bringing grace to many. For me, this also mirrors the life of Martin Luther, amongst others. I see him in in the role of the manager being accused of mismanaging his Father's possessions. Facing a ban on his books and being excommunicated from the church, he unabatedly preached the forgiveness of sins as a free gift from God received by faith alone. Furthermore, being as wise as the children of this world, he also made use of the technology of his time, the printing press, to scatter the Word of God to all corners of this world. He did this, of course, against the background of and motivated by his own debt being cancelled by a gracious God. The pureness of the Gospel is intrinsically related to God's mercy. 


\section{Acknowledgements}

Competing interests

The author declares that he has no financial or personal relationship(s) which may have inappropriately influenced him in writing this article.

\section{References}

Baudler, G., 1986, Jesus im Spiegel seiner Gleichnisse: Das erzählerische Lebenswerk Jesu - ein Zugang zum Glauben, Calwer, Kösel.

Blomberg, G.L., 2004, Preaching the parables: From responsible interpretation to powerful proclamation, Baker Academics, Grand Rapids.

Ellis, E.E. (ed.), 1974, The Gospel of Luke Marshall, Morgan \& Scott, London. (New Century Bible commentary).

Forbes, G.W., 2000, The God of old: The role of the Lukan parables in the purpose of Luke's Gospel, Academic Press, Sheffield.

Fitzmyer, J., 1964, 'The story of the dishonest manager (Lk 16:1-13)', Theological Studies 25, 23-42.

Harrison, M.C. \& Pless, J.T. (eds.), 2012, Women Pastors? The ordination of women in biblical Lutheran perspective, Concordia Publishing House, St Louis.

Herzog II, W.R., 1994, Parables as subversive speech: Jesus as pedagogue of the oppressed, Westminster/John Knox, Louisville.

Hultgren, J.H., 2000, The Parables of Jesus: A Commentary, William B. Eerdmans, Grand Rapids.

Jeremias, J., [1963] 1984, Die Gleichnisse Jesu, 9. Auflage, Vandenhoeck \& Ruprecht, Göttingen.
Kittle, G., 2002/2003, 'Vorletzter Sonntag des Kirchenjahres, Lukas 16, 1-8(9)', in Göttinger Predigmeditationen, 57. Jahrgang, pp. 506-512, Vandenhoeck \& Ruprecht, Göttingen.

Kloppenberg, J.S., 1989, 'The dishonest manager', Biblica 70, 474-494.

Louw, J.P. \& Nida, E.A., 1988, Greek-English Lexicon of the New Testament based on semantic domains, vol. 1, United Bible Society, New York.

Malina, B.J., 1988, 'Patron and client: The analogy behind Synoptic theology', Forum 4, 2-32.

Malina, B.J., 1993, The New Testament world: Insights from cultural anthropology, Westminster/John Knox, Louisville.

Malina, B.J. \& Rohrbaugh, R.L., 1992, Social science commentary on the Synoptic Gospels, Fortress Press, Minneapolis. PMCid:275558

Moxnes, H., 1991, 'Patron-client relations and the new community in Luke-Acts', in J.H. Neyrey (ed.), The social world of Luke-Acts: Models for interpretation, pp. 241-268, Peabody, Hendrickson.

Reinstorf, D.H., 2002, 'Methaphorical stories in Luke's narrative world: A challenge to a conventionl worldview', PhD dissertation, University of Pretoria.

Reinstorf, D.H., \& Van Aarde, A.G., 1998, 'Jesus' kingdom parables as metaphorical stories: A challenge to a conventional worldview', HTS Teologieses Studies/ Theological Studies 54(3/4), 603-622. http://dx.doi.org/10.4102/hts. v54i3\&4.1436

Scott, B.B., 1990, Hear then the parables: A commentary on the parables of Jesus, Fortress, Minnapolis.

Van Aarde, A.G., 2012, "Verset teen mag: Die pilgrim se reis in drie "Sondergut" gelykenisse in Lukas 15 en 16', HTS Theologiese Studies/Theological Studies 68(1), 277-287. http://dx.doi.org/10.4102/hts.v68i1.1032

Van Eck, E., 2011, 'Do not question my honour: A social-scientific reading of the parable of the minas (Lk 19:12b-24, 27)', HTS Teologiese Studies/Theological Studies 67(3), 254-264. http://dx.doi.org/10.4102/hts.v67i3.977

Wright, S.L., 2000, 'Parables on poverty and riches', in R.N. Longenecker (ed.), The Challenges of Jesus' Parables, pp. 217-239, William B. Eerdmans, Grand Rapids. 